\title{
An overview of anaemia
}

Keywords: anaemia, haemoglobin, sickle, microcytic, normocytic, macrocytic

Abbreviations: g/dl, gram per deciliter; Fl, femtolitre; G6PD, glucose-6-phosphate dehydrogenase deficiency

\section{Introduction}

Anaemia is a commonly used term in clinical settings. Etymologically, it is from Greek (An-no or lacking; haemia-blood). It is important that anaemia does not lose its meaning, so that patients will continue to receive proper care.

\section{Definition}

Anaemia can be defined as a decrease in the number of red blood cells or their haemoglobin content, for an individual's age, sex or altitude. Anaemia is not a disease or diagnosis but a clinico-pathologic condition. It requires thorough investigation. It is estimated that about $30 \%$ of the world population is anaemic and half of these, some 600million people, have iron deficiency. ${ }^{1}$ Although normal haemoglobin values can vary between laboratories, typical values would be less than $13.5 \mathrm{~g} / \mathrm{dl}$ in adult males and less than $11.5 \mathrm{~g} / \mathrm{dl}$ in adult females. From the age of 2 years to puberty, less than $11.0 \mathrm{~g} /$ $\mathrm{dl}$ indicates anaemia. As newborn infants have a high haemoglobin level, $14.0 \mathrm{~g} / \mathrm{dl}$ is taken as the lower limit at birth. ${ }^{2}$

\section{Classification}

The morphological classification is given here. ${ }^{2}$

\section{Microcytic anaemia}

The red blood cells appear small microscopically. Mean corpuscular volume is $<80 \mathrm{fl}$. Causes of this type include iron deficiency anaemia, thalassaemia, anaemia of chronic disease (some cases), lead poisoning and sideroblastic anaemia.

\section{Normocytic anaemia}

The red blood cells are normal in size microscopically. Mean corpuscular volume is $80-95 \mathrm{fl}$. Causes of this type include many haemolytic anaemias (e.g. sickle cell anaemia), anaemia of chronic disease (some cases), acute blood loss, renal disease, mixed deficiencies and bone marrow failure.

\section{Macrocytic anaemia}

The red blood cells appear larger than normal microscopically. Mean corpuscular volume is $>95 \mathrm{fl}$. Causes of this type may be megaloblastic or non-megaloblastic. Megaloblastic causes include vitamin $B_{12}$ deficiency or folate deficiency. Non-megaloblastic causes include alcohol, liver disease, myelodysplasia, aplastic anaemia, etc.

\section{Clinical features}

\section{Symptoms $^{3}$}
i. Fatigue
ii. Breathlessness

\author{
Volume 3 Issue 6 - 2017
}

ljachi Ochoche Ochola, ' Audu Onyemocho² 'College of Health Sciences, Benue State University, Nigeria ${ }^{2}$ Department of Epidemiology and Community Health, Benue State University Teaching Hospital, Nigeria

\section{Correspondence: ljachi Ochoche Ochola, College of Health Sciences, Benue State University, Makurdi, Nigeria,} Email ocholaijachi@gmail.com

Received: April 22, 2017| Published: September 20, 2017 iii. Malaise

iv. Angina

v. Dizziness

vi. Paresthesiae

vii. Visual disturbances

viii. Symptoms of the underlying cause:

ix. Bone Pain and jaundice in sickle cell disease

$\mathrm{x}$. Passage of dark urine in G6PD deficiency

xi. Symptoms associated with severe malnutrition

xii. Symptoms of complications e.g. severe dyspnoea and edema in heart failure

\section{Signs. ${ }^{2}$}

General signs: include pallor of mucous membranes, tachycardia, bounding pulse, systolic flow murmur and signs of heart failure. The tongue is said to be the most accurate site for the detection of pallor caused by anemia. ${ }^{4}$

Specific: associated with a particular cause such as koilonychia (spoon nails) in iron deficiency, jaundice in haemolytic anaemia and leg ulcers in sickle cell anaemia.

\section{Assessment}

Basically, an assessment requires:
i. A comprehensive history.
ii. A thorough physical examination.
iii. Full blood count with differentials.
iv. Peripheral blood film.

Further investigations are directed at the likely cause (e.g. iron studies, thick and thin films, serum bilirubin, haemoglobin electrophoresis and bone marrow examination) or complication.

\section{Management}

Management may involve dietary improvement, nutritional 
supplementation, administration of haematinics, administration of antimicrobials, avoidance of implicated drugs or foods, blood transfusion, splenectomy and bone marrow transplant. Exact action is directed at the cause of anaemia along with other instituted treatment. Blood transfusion may not be necessary in a well-compensated patient with chronic anaemia.

\section{Nursing}
i. Health history and examination.
ii. Ensuring optimal in-patient overall care
iii. Monitoring of vital signs especially during blood transfusion.
iv. Ensuring adequate nutrition.
v. Ensuring compliance with treatment.
vi. Identification of patient risk factors with a view to preventing recurrence.
vii. Educating the patient about his condition.

\section{Acknowledgements}

I acknowledge the contributions of Dr. Audu Onyemocho.

\section{Conflict of interest}

The author declares no conflict of interest.

\section{References}

1. Watson HG, Craig JIO, Manson LM. Blood disease. In: Walker RB, Colledge NR, editors. Davidson's Principles and Practice of Medicine. 22nd ed. Edinburgh, Scotland: Churchill Livingstone/Elsevier; 2014. $1021 \mathrm{p}$.

2. Hoffbrand AV, Moss PAH. Essential Haematology. 6th ed. Oxford, England: Wiley-Blackwell; 2011. p. 24-27.

3. Falase AO, Akinkugbe . A Compendium of Clinical Medicine. 2nd ed. Ibadan, Nigeria: Spectrum Books Ltd; 2007. 370 p.

4. Kalantri A, Karambelkar M, Joshi R. Accuracy and reliability of pallor for detecting anaemia: a hospital-based diagnostic accuracy study. PLoS One. 2010;1(5):e8545. 